\title{
Family involvement and educational success of the children of immigrants in Europe. Comparative perspectives
}

\author{
Philipp Schnell ${ }^{*}$, Rosita Fibbi ${ }^{1}$, Maurice Crul $^{2}$ and Martha Montero-Sieburth ${ }^{3}$
}

\author{
* Correspondence: \\ philipp.schnell@univie.ac.at \\ ${ }^{1}$ Swiss Forum for Migration and \\ Population Studies, University of \\ Neuchatel, Neuchatel, Switzerland \\ Full list of author information is \\ available at the end of the article
}

\begin{abstract}
Recent literature has emphasised the importance of family involvement within immigrant families in determining their children's educational pathways. On the one hand, the focus on family involvement and the transmission of familial resources becomes more important when disentangling ethnic educational inequalities for second-generation youth. On the other hand, particular practices of family involvement seem to counterbalance disadvantaged origins and become the driving force for educational success. However, few, if any, studies systematically explore the importance of family involvement for educational success by children of immigrants from an international comparative perspective. This introduction paper attempts to fill this gap. In addition to previewing the contents of the articles found in this issue, we include a comparative review of the main communalities found in the contributions of this special issue. The paper concludes with suggestions for future comparative research on family involvement and educational success by children of immigrants in Europe.
\end{abstract}

Keywords: Family involvement; Children of immigrants; Second generation; Education; Success; Integration

\section{至

\section{Introduction}

Research on the educational trajectories and achievements of the children of immigrants in Europe has attracted a great deal of scholarly attention, as well as public interest. Fairly stable patterns have been documented in past studies showing the substantial educational disadvantages faced by immigrant youths across Europe (see Crul, Schnell, Herzog-Punzenberger et al. 2012; Heath, Rothon, \& Kilpi, 2008 for NorthWestern Europe; Schnell \& Azzolini, 2015 for Southern Europe). Yet, some diversity in educational trajectories and outcomes of the children of immigrants within and between European countries is apparent.

Overall, for children of immigrants, educational trajectories and achievements vary according to parental socioeconomic backgrounds, home environments, and the neighbourhood and school contexts. However, the factor that most strongly predicts educational pathways for children of immigrants and explains their disadvantaged positions compared to the majority student population tends to be socioeconomic background,

(c) 2015 Schnell et al. This is an Open Access article distributed under the terms of the Creative Commons Attribution License (http:// creativecommons.org/licenses/by/4.0), which permits unrestricted use, distribution, and reproduction in any medium, provided the original work is properly credited. 
i.e. the social class position of their parents (Glick \& White, 2003; Heath \& Brinbaum, 2007; Kao \& Thompson, 2003).

Within the past two decades, research has emphasised the increasing importance of family support and parental involvement within immigrant families in determining educational pathways. On the one hand, social class reproduction for children of immigrants is influenced by the transmission of resources and the quality of ties between generations (Charles, Roscigno, \& Torres, 2007; Rosenbaum \& Rochford, 2008). Thus, the focus on family involvement and the transmission of familial resources becomes important when disentangling ethnic educational inequalities for second-generation youth. On the other hand, experiences of intergenerational upward mobility amongst disadvantaged young adults of immigrant origin demonstrate that social reproduction theory may be subject to exceptions.

Amongst the factors which counterbalance the impact of disadvantaged origin, the literature ascribes special importance to parental involvement in children's upbringing and education. Several studies have shown that there is a growing number of secondgeneration youth achieving educational success despite their low social class backgrounds. High parental ambitions, expectations, aspirations and specific types of parental support have been found to be the driving force for these successful achievements amongst young adults of immigrant origin (Brinbaum \& Kieffer, 2009; Crul, Zhou, Lee et al. 2012; Portes \& Fernandez-Kelly, 2008; Santelli, 2013; Schnell, Keskiner, \& Crul, 2013). While researchers have started to increasingly focus on the relationship between family involvement and educational outcomes ${ }^{1}$, few - if any - studies have systematically explored the importance of family involvement for upward mobility and educational achievement by children of immigrants in Europe from a comparative and cross-national perspective.

There is ample evidence from US studies that family involvement in immigrant families is stratified by ethnic origin and parental support. Results reveal that some ethnic origin groups have lower levels of school involvement than their majority counterparts, while other ethnic origin groups actually show higher levels of family involvement (Kao, 2004; Kao \& Joyner, 2004; Turney \& Kao, 2009). Evidence on whether family involvement varies between different immigrant origin groups within European countries is largely missing. Moreover, studies looking systematically at family involvement and possible variations within the same origin group across several European countries are scarce (for exceptions, however, see Crul, 2013; Schnell, 2014; Schnell \& Crul, 2014).

Additionally, family involvement is oftentimes narrowly framed to include only the role played by parents. So far, very few studies exist that extend the discussion of family involvement to other significant family agents, such as siblings or kinship members in the wider ethnic community in Europe. This is somewhat surprising given that siblings or community members can also be a significant resource in overcoming family disadvantage, as shown, for example, by Zhou and Bankston (1998) in their study on Vietnamese youth or by Fernandez-Kelly for Latinos (2008) in the US and in Crul's work on school achievement by second-generation Turks and Moroccans in the Netherlands (Crul, 1999, 2000).

This special issue is an attempt to fill these identified gaps in the current literature. It deals with the issue of family involvement in immigrant families and its association with educational success and the processes of upward mobility for their children in Europe 
Such a focus implies that this collection of papers falls within the scope of a resource approach to immigrants' trajectories in the country of residence which has superseded the hitherto dominant deficit paradigm in this field which has prevailed particularly in education and in studies of stratification. Taken together, the five contributions in this special issue ask whether there are common patterns of family involvement observable across ethnic origin groups within and between European countries. Which patterns and types of family involvement are behind the success attained by children of immigrants in Europe? And which strategies of involvement can be identified for immigrant families across Europe to achieve upward mobility for their children?

The remainder of this introductory paper is structured as follows: We start by conceptualising family involvement and further differentiate dimensions of it from a broader theoretical framework. We pay particular interest to the interplay between these different forms of involvement and educational success for children of immigrants. Next, we discuss to what extent involvement in immigrant families is stratified by socioeconomic background and how far it correlates with additional family characteristics, such as their length of residence or parental aspirations. We do so in order to investigate how far second-generation youth in Europe might be advantaged or disadvantaged in their access to within-family resources.

The following section then reviews the contributions in this issue and describes what we think each paper adds to our understanding about the importance of family involvement and educational success by children of immigrants in Europe. In the fourth section, we highlight similarities in outcomes in a comparative way. We are particularly interested in similarities that emerge from contributions by different authors since they indicate common processes for children of immigrants across a number of selected European countries. Finally, we conclude this introduction by arguing in favour of more systematic research on family involvement and educational outcomes by children of immigrants in order to better understand divergent pathways to educational success.

\section{Family involvement and educational achievement}

\section{Family involvement: styles, aspirations, practices and resource mobilization}

Research on the impact of parenting on a child's academic achievement has followed two main theoretical traditions, namely parenting style and practices (Darling \& Steinberg, 1993). Parenting styles express the emotional climate in which parents raise their children, while parenting practices are specific behaviours that parents use to socialise their children. Parental involvement is often conceptualised as a part of parental practices.

The specificity of parental involvement is its focus on school issues (Jeynes, 2007) ${ }^{2}$. In her seminal work, Epstein (1987) identified four types of involvement from the perspective of what schools can do in order to incorporate parents: (1) basic obligations, establishing physical and psychological structures for homework performance, interacting with the school or teacher about homework; (2) school-to-home communications; (3) parent involvement at school, visiting the school, volunteering at the school and (4) parent involvement in learning activities at home, i.e. reading, discussing school topics, managing the child's time and providing a favourable learning environment. Epstein's typology has influenced the conceptualisation of involvement from the perspective of the parents, complementary to the school perspective. The construct has therefore 
been enlarged to include on one side goals and aspirations which inspires practices, and on the other side resources mobilisation which aims at enhancing the impact of practices (Fan \& Chen, 2001; Jeynes, 2007).

Most importantly, many hypothesise that children benefit from parental involvement in their education. After all parents are their first educators. This manifests through a number of different mechanisms: First, parental involvement socialises children by showing that education is valued and of importance to the family, which may ultimately translate into greater appreciation of education on the part of the children themselves. Parental involvement provides parents with a means of social control. They get to know about their children's schooling through directly controlling the time their children spend on reading and completing homework. Additionally, they get to know other parents and teachers with whom they discuss their children's performances. Lastly, involved parents are privy to substantially more information about their children. Through these mechanisms, parental involvement has a lasting influence on the educational performance of their children, and most researchers have found that higher levels of parental influence lead to significant academic advantages and outcomes.

While retaining the larger construct of parental involvement from the parents' perspective, the authors of the papers in this volume build their studies on the further extended notion of family involvement by encompassing the whole family as actors in the process; siblings and relatives may also provide support to the younger members of the family (Malecki \& Demaray, 2003).

Family involvement in a child's life and schooling is most often considered a form of social capital, be it home-based - such as parent-child or siblings interactions and communication - or school-based - such as participation in school and relations with teachers (Pong et al. 2005). Social capital is understood as a set of networks and connections in which actors secure benefits and resources by virtue of membership and contacts. As for its structural form, family involvement entails dyadic relationships between the parent and the child (other family member and the child, family member and teacher). The kinship-base of family involvement makes it possible to situate the dyadic relationship in the normative frame of obligation and reciprocity. Families have their own human and financial capital to invest in children: from this perspective, parents' social relationships facilitate their children's school performance.

Investing in social relationships is a way of building up social resources, which represent a powerful instrument - along with financial resources - to be converted into human capital (Coleman, 1988). Yet families may draw potential resources from outside the network: in this sense, social capital is a multiplier of an individual's own (cultural) capital (Bourdieu, 1980). Bourdieu, as well as Lareau (2002), defines cultural capital as symbolic knowledge useful in understanding how the social world works that can be passed on within families. Social capital, by contrast, refers to the ability of families to manage successfully the material and symbolic resources that they possess for the benefit of their members. Bourdieu stresses the importance of the cultural capital necessary to activate social capital, thus suggesting that how the social networks are used may be as valuable (or even more so) than social networks themselves (Furstenberg \& Kaplan, 2003). Those two conceptualisations emphasise different yet compatible dimensions of social capital: the first stresses the form of social capital, whilst the second highlights the process through which social capital affects children's behaviours (Mcneal, 1999). 


\section{Family involvement and school achievement}

There are conflicting empirical findings and considerable inconsistencies regarding the relationship between parental involvement and a student's academic achievement (Fan \& Chen, 2001; McNeal, 2012). Whereas some authors assert that parental involvement is generally a salient factor in explaining behavioral but not cognitive outcomes (McNeal, 1999), others underline the undeniable role played in children's outcomes by various types of social support provided by parents, family members, significant others and peers (Jeynes, 2007; Malecki \& Demaray, 2003; Spera, 2005). Fan \& Chen (2001) observe a small to moderate, and practically meaningful, relationship between parental involvement and academic achievement. Parental aspirations have been found to have the strongest relationship with students' academic achievement among various components of parental involvement, once parental socioeconomic status is held constant (Lee \& Bowen, 2006). In the meta-analysis on the impact of various components of parental involvement on children's achievement, Jeynes asserts that parental expectations have the largest effect on achievement, followed by parenting style while the effects of parents checking homework as well as family communication are fairly lower (Jeynes, 2007).

Parent-school involvement and intergenerational closeness have been found to be positively related to the educational outcomes of the children of immigrants (Pong et al. 2005) and their social mobility in general (Santelli, 2013). Many authors assessed a positive link between parenting practices and achievement. Yet, Dornbusch et al. (1987) found for the US that authoritative parenting was associated with higher grades for white families but not for Asian, Black and Hispanic families. Similar results are found by Steinberg et al. (1992) concerning white, Black and Hispanic families. Although recent research by Portes and Rivas (2011) indicates that authoritative parenting pays off for Latino students who become high achievers. Jeynes (2007) states that parental involvement is associated with higher achievement also for the "racial minority student" and that parental involvement is a means to reducing the achievement gap that exists between white students and some racial minority students.

\section{Variations in family involvement}

Previous research has shown that involvement with their child's schooling in immigrant families is shaped by the resources and opportunities available to them and varies by ethnic origin.

To begin with, empirical evidence suggests that the lower socioeconomic status of many immigrant families translates into a limited amount of school-related resources available to invest in and transmit to their children in order to support their educational trajectories. Social class differences in parents' norms, practices and styles have been further demonstrated by many authors. For example, Lareau (2002) distinguishes between middle-class parents who manage to smooth their children's way to educational mobility through "concerted cultivation" by actively developing children's skills and talents, and working class families who, in spite of their undeniable support for their children follow a child-rearing logic of "natural growth" (presuming that their children will go on and thrive spontaneously). As she concludes, race has much less impact on school achievement than social class. In American literature the issue of social class is oftentimes intertwined with race/ethnicity under the overarching concept 
of 'minority' condition. "Differentials in parental investments provide little support for cultural distinctiveness" (Charles et al. 2007, p. 348). Lareau \& Mc Namara Horvat (1999) indicate that ethnic minority parents tend to be less involved in their children's education. However, this is not due to the fact that they value education less than majority parents (Ryan, Casas, Kelly-Vance, Ryalls, \& Nero, 2010). Lee \& Bowen (2006) find that while European-American parents show higher involvement in school, African-American and Latino parents deploy a stricter management of their children's time. In Latino families, parental involvement at home is greater than at school and based on more involvement of significant others and also greater in those families (Ryan et al., 2010).

Involvement by immigrant parents might also be affected by the limited familiarity with their children's educational system, preventing even the more educated and skilled immigrant parents from providing effective support for their children's education. Others found that the time availability within families is crucial for involvement and that due to the rotating shift work in many blue collar jobs held by immigrant parents, these families lack time to effectively support their children in school related matters (Gauthier, Smeedeng, \& Furstenberg, 2004). Family size also seems to matter in the distribution of resources spread across several children and the degree of family involvement. With increasing numbers of children within families, parental involvement (e.g. parental attention or supervision) declines (Downey, 1995, 2001). Overall, the extent to which immigrant families are relatively advantaged or disadvantaged in their access to and quality of within-family resources are shaped by important family characteristics and the available opportunities to them.

Despite these disadvantages, immigrant families are oftentimes characterised by stronger emotional bonds and closeness than families in the majority population, providing greater psychological security and support for their children to achieve educational success (Pong et al. 2005; Rosenbaum \& Rochford, 2008). As some have argued, this closeness is accompanied by greater levels of parental aspirations within immigrant families that might translate into more superior educational performances and greater levels of success for children of immigrants. As Kao and Tienda (1995) argued, children of immigrants might be more committed than the majority population to the idea that education is a springboard for upward mobility, because of the shared experiences for a better life by their parents. Frequent reminders that education might be the only channel to escape from the current familial circumstances, combined with closely bonded ties between family members, might cross-cut the aforementioned barriers to family involvement and frequently translates into successful performances by the children of immigrants (Portes \& Fernandez-Kelly, 2008).

\section{New insights on family involvement and educational achievement - overview of the issue}

In this special issue we bring together five papers that focus on family involvement and the educational success of children of immigrants. Given that family involvement is a multidimensional concept and includes parents as well as siblings as significant supportive actors within families, we purposively gave our contributors wide latitude in defining involvement through the family and the relationship to educational 
achievement within their papers. Consequently, the contributions describe various ways of family involvement, highlight reasons for it in familial discourse as well as how children perceive it and how it effects their educational achievements. Moreover, some contributions in this special issue extend the current discussion about family involvement by investigating simultaneously the supporting behavior of parents and elderly siblings. Our contributors apply rather different methods and datasets to examine the role played by family involvement for educational success by children of immigrants. Two papers use qualitative interviews as major sources, one paper employs representative data from a specific survey on immigrants and their descendants while three papers rely on both quantitative and qualitative data collected from the second-generation. The papers in this special issue also use different measures of 'educational success' as a dependent variable as they are often restricted by the availability in their datasets and empirical materials. Nevertheless, they always employ the best available indicators which represent educational success in the contexts of the countries under consideration. Thus, family involvement is related to the highest educational attainment or to overcoming low achievement, while others focus on specific moments in the educational pathways of second generation youths that lead to prestigious academic credentials. All papers are comparative in nature, either comparing children of immigrants from the 'same' ethnic origin group across North-Western European countries or exploring ethnic differentials in family involvement and educational success between different origin groups within one country. Yet, some further explore group differences within one dominant ethnic origin group in one country. However, irrespective of the different approaches to the link between family involvement and educational success, all contributions help to disentangle whether there are common processes and similarities across different countries for children of immigrants when it comes to family involvement and educational success.

The collection starts with a paper by Rosita Fibbi and Jasmine Truong which deals with the differences within the Kosovar community, one of the largest second generation groups today in Switzerland and regarded in public opinion as a problematic group. Having assessed in previous studies the importance of intergenerational social mobility in this group (Fibbi et al. 2015), this paper explores the impact of parental involvement in children's school trajectories, thus highlighting within-group differences. This qualitative study analyses interviews conducted in 2013 in the Germanspeaking Zurich area of Switzerland with twenty young persons and one of their parents in Kosovar families. Families whose child experienced a highly mobile path, achieving tertiary education, are contrasted with families whose child experienced reduced mobility. Significant differences are found within the Albanian-speaking group: variation in parental educational attainment in the country of origin, as well as professional mobility in the country of immigration translate into educational outcomes for their children through the mediating effect of parenting styles, involvement and practices. All parents show an important emotional involvement in their child's school trajectory; yet, parenting style relates quite closely to the type of parental school involvement and resource mobilisation. Educational success is associated with an authoritative parenting style practised by parents of various socio-cultural backgrounds. On the contrary, lack of educational success is to be found in families where parents 
cannot provide supporting to their children, whatever their previous educational achievement is.

The following paper, by Sara Rezai, Maurice Crul, Sabine Severiens and Elif Keskiner, draws on 86 in-depth interviews with second generation men and women of Turkish and Moroccan background in the Netherlands. All of their respondents originate from low socioeconomic family backgrounds but have achieved upward educational mobility and completed higher education in the Netherlands. Rezai and her colleagues apply the (slightly modified) framework of House (1981) to investigate patterns of family involvement and educational success in which they distinguish between informational, notional, emotional and instrumental support second-generation Turks and Moroccans receive from their parents. Their findings reveal that informational support, such as homework or study advice, is the least common type of support that immigrant parents provide to their children, partially because these parents lack adequate language skills, sufficient knowledge of the Dutch education system and have generally low levels of education. This finding is in line with the results presented in the paper by Schnell within this special issue and also the research literature for parental involvement from the U.S. The paper by Rezai et al. suggests, however, that other types of parental involvement, such as emotional, notional and instrumental support are not only frequent, but also perceived by the successful second generation as essential for their accomplishments. For example, strong family discipline combined with emotional support seems to translate into higher aspirations for second-generation young adults and becomes a major factor for their upward mobility. Such types of parental support are often driven by parental aspirations and their persistent wish to set their children on the right track to achieving upward mobility. In turn, the second generation frequently provide their younger siblings and relatives, and children of friends and acquaintances with what they consider to be essential support for successful navigation through the Dutch education system, which - unlike the parental support they received themselves - primarily consists of informational support.

The paper by Laure Moguérou and Emmanuelle Santelli continues the line of research set out in the article of Rezai and colleagues by exploring involvement and support strategies in immigrant families and thereby simultaneously examining the role of parents and older siblings. Focusing on immigrant and majority families in France, the authors report results from their analyses using the "Trajectories and Origins" Survey (2008) and 42 post-survey interviews conducted with descendants of Turkish, Maghreb or Sub-Saharan African origin from working class backgrounds. Their quantitative analysis reveals that informational support, such as concrete help with homework, is found to be less frequent among immigrant parents in France. Results from the author's postsurvey interviews uncover, however, that immigrant parents develop alternative ways of getting involved in their children's schooling activities in order to compensate for the lack of instrumental support. The most frequent ways include recurring talks on school matters and the importance of achieving upward mobility. These compensation strategies are driven by parental aspirations, but are less effective for the educational success of their children if they are not accompanied by tangible actions, such as - for example - homework control. Moguérou and Santelli's results further show that these tangible actions are often provided by the oldest child in the family home. Disentangling these compensating strategies shows that immigrant parents in France make 
greater emotional and material investments in the oldest child, who then - accompanied with their own educational experience - becomes the responsible person for providing educational (instrumental) support for their younger siblings in the family. This transmission pattern through the eldest child appears significantly more often in immigrant families than majority families. Through an investment in the oldest child, immigrant parents transform their general aspirations for upward mobility into concrete and specific types of support with the help of the oldest child. The relationships between siblings then mitigates obstacles and might even facilitate educational success. Different levels in the allegiance to their parents' upward mobility project therefore also explain differences in educational outcomes amongst children of immigrants across ethnic origin groups in France.

The two articles that follow, by Philipp Schnell and Elif Keskiner, compare aspects of family involvement within Turkish families across a number of selected European countries and cities and look at how it is linked to schooling trajectories and educational attainment by their descendants. Unlike many previous studies that frequently investigate ethnic differentials in family involvement and their effects on educational achievement within countries, Schnell and Keskiner use a particular variant of a divergent comparison by considering the 'same ethnic origin group' (Turks) with comparable starting positions among the second-generation across countries with rather different education systems.

Schnell's article explores the school-related involvement strategies and patterns of support provided within Turkish families by parents and older siblings in three selected North-Western European countries, namely Austria, France and Sweden. The three countries differ with respect to the institutional settings of the education systems. Family involvement is conceptualised as a multidimensional construct, including parental control and instrumental support. Using data from the TIES survey, the study first examines descriptively the frequency of family support and how these involvement patterns are related to additional correlates, such as parental socio-economic background, family composition or length of residence. Findings show that parental involvement by Turkish parents and older siblings is on average most frequent in Austria, followed by France, and least frequent in Sweden. At the same time, the magnitude of the correlates between parental and siblings involvement and certain compositional family factors were greatest in Austria. Using a series of binomial logistic regressions, results suggest that the educational attainment of second-generation Turks in Austria is much more dependent on various activities of support provided by their parents when compared to their counterparts in France and Sweden after holding family background characteristics constant. Besides, the educational success of second-generation Turks in Austria is reliant on the extra support they receive from older siblings - beyond parental involvement and educational background. Again, as Schnell demonstrates, no such significant effects were observed for sibling support in either France or Sweden. In a last step, the paper reveals that second-generation Turks are still more reliant on educational support from their parents than the children of majority families within Austria which was not the case in either France or Sweden. Schnell's paper suggests that these different findings across countries have to be read in the light of interaction mechanisms with institutional settings of the given education systems. The family becomes the main focal point of an education system which due to its half-day training system delegates 
learning and homework to the family home. By contrast, in the case of systems such as those in France and Sweden - offering full-time education and supervised homework sessions in schools - the role of additional help provided by parents at home becomes less important.

Finally, Keskiner's paper poses the question of whether it is merit or parental involvement that matters for second-generation Turks to successfully navigate through the first selection moment in the French and Dutch education system. These first selection moments are the most crucial branching points in both education systems and largely determine educational careers of young pupils and their access to prestigious academic trajectories (Brinbaum \& Cebolla-Boado, 2007; Tolsma, Coenders, \& Lubbers, 2007). Keskiner defines involvement as parental aspirations, preferences and particular strategies for school choices on behalf of children. Summarising these sub-dimensions of parental involvement as cultural capital, Keskiner pays particular attention to the mechanisms through which cultural capital by Turkish parents facilitates advancement and favourable conditions in the first selection moment in the two different contexts. Using information from qualitative interviews with descendants of Turkish immigrants in Amsterdam and Strasbourg, and analysing respective quantitative data from the TIES survey, she examines how the two different settings in France and the Netherlands are responsive to forms of parental involvement next to the meritocratic achievements of young people. In the case of Amsterdam, the education system limits direct parental involvement in the selection process. As a result, the tracking decisions are largely determined by previous test scores, i.e. the Dutch achievement scores (CITO). In contrast, in the case of Strasbourg, cultural capital by immigrant parents makes a difference for their children's tracking decision as the French education system allows for active participation by parents. As she concludes, this finding might explain the larger numbers of students in the academic track in Strasbourg compared to Amsterdam and contributes therefore to the explanation of cross-national differences in outcomes among the Turkish second-generation between France and the Netherlands.

\section{Family involvement and educational success: comparative perspectives}

This special issue brings together five papers by scholars from various European countries who studied involvement practices in immigrant families and its links to educational success and upward mobility by their children. Although the contributions cover different countries and cities, various ethnic origin groups and different measures of educational success, the common scheme running through all the articles is whether and what kind of family involvement translates into educational success for children of immigrants against the backdrop of structural and familial disadvantage. We now depart from their findings and turn to a number of important similarities that are evident for immigrant families in the different European countries. The results presented in this issue show some clear converging patterns.

To begin with, and irrespective of the countries or groups examined, all papers report that immigrant parents commend and value education as they perceive it as the most legitimate instrument to secure and even advance their social status in the immigration societies. Therefore, immigrant parents psychologically and emotionally support their children on their way to educational credentials by exhorting their child to take up the challenge of school work (Rezai et al., Moguérou \& Santelli) and by 
providing care and trust or by mobilizing scarce economic resources (Fibbi \& Truong). Most importantly, as shown for example in the contributions by Keskiner and in particular by Rezai and colleagues, these types of "soft" involvement can help to overcome disadvantage and achieve educational success. Despite their disadvantaged position in society, the papers in this special issue show that immigrant families are oftentimes characterised by stronger emotional bonds and closeness than families in the majority population. They provide greater psychological security and support for their children to achieve educational success, a finding that is in line with the international literature on family involvement by immigrants (Pong et al. 2005; Rosenbaum \& Rochford, 2008).

Similarly, almost all papers within this special issue mention relatively high parental aspirations as a distinguishing feature of immigrant families although some manage to navigate between setting high goals and taking into account the effective performances of their children better than others. Those findings are likely to substantiate the immigrant optimism hypothesis (Kao \& Tienda 1995) which stresses how parental aspirations are reported on children in the context of the receiving country, where better opportunities make those aspirations more plausible. At the same time, as Moguérou \& Santelli state in their paper on immigrant families in France, there appears a substantial gap between high parental aspirations which are oftentimes rather abstract and general and the effective support they can provide, such as concrete help with homework. However, as many of the contributions show (e.g. Keskiner, Rezai et al., Moguérou \& Santelli), high parental aspirations are frequently the foundation for alternative involvement strategies and supportive family environments characterized by strong intergenerational closure.

Contributions comparing immigrant to majority families of similar socioeconomic background notice that family participation in school related activities (e.g. help with homework and meeting with teachers) is less frequent in immigrant families within all countries (Fibbi \& Truong, Moguérou \& Santelli, Rezai et al.). This kind of involvement is most likely linked to parental educational background as well as language skills. Schnell however finds no significant link between parental knowledge of local language and children's school achievement, once parental education is controlled for. Such an observation might suggest that the most decisive factor is not so much language mastery but parental capacity to secure a supportive family environment.

Families' mobilization of social and cultural capital and hence the ability to provide valuable information and orientation appear in many papers (Fibbi \& Truong, Moguérou \& Santelli, Rezai et al.) as a decisive factor explaining educational attainment in general and education success in particular. Variations in family involvement across ethnic groups appear largely explained by different migration trajectories of the parents and their different opportunities within the receiving societies, as this is best shown in the quantitative approaches of Schnell and Moguérou \& Santelli. This might be linked to the experiences of immigrant parents: whether they remain stuck in unwarranted labor and family situation or manage to avoid such downturns (Fibbi \& Truong).

The most consistent finding reported by our contributors is that if immigrant families are at a disadvantage in various aspects, they develop compensatory strategies in order to overcome these drawbacks - a finding that is evident for many immigrant origin groups in different European countries. Mobilization of (older) siblings is among the 
most frequent compensation strategies. Thus, while papers comparing various immigrant groups in a quantitative way, such as the paper by Moguérou \& Santelli, on France, do assess the parental involvement to be lower in some immigrant families, such as for example in Turkish families, they also show that exactly in those families siblings play a crucial role, especially in providing homework help and giving advice. The inclusion of older siblings in the family support is highlighted in various other papers (Schnell and Fibbi \& Truong). Parents frequently provide greater emotional and material investments in the oldest child, who then becomes the responsible person for providing educational support for their younger brothers and sisters. Moguérou \& Santelli notice that parents require such assistance from the older siblings because they have schooling experiences and knowledge on the workings of the education system. This compensating strategy through older siblings appears significantly more often in immigrant families than majority families.

The second practice that compensatory strategies may take is reaching out for external help outside the (nuclear) family circle. This is mentioned in almost all the papers. Mobilization of external resources in the community or at school requires, however, social competences and social capital. In sum, previous research on family involvement and educational achievements by children of immigrants has predominately focused on the narrow role played by parents and the resources available within the nuclear family. The papers within this special issue have uncovered relevant other compensation strategies in immigrant families. The arguments and findings documented here, then, suggest that the discussion on family involvement and educational achievement by children of immigrants needs to be substantially enhanced in order to fully understand patterns of upward mobility and educational success.

Finally, the cross-national comparisons show that different institutional settings of education systems determine the relevance of family involvement for educational success by children of immigrants. As shown for example in the contribution by Schnell, some education systems in Europe (i.e. Austria) request greater amounts of family involvement for the successful schooling trajectories of young students than do other countries' schooling systems (e.g. France or Sweden). Given that immigrant parents frequently face barriers to involvement (such as insufficient language skills), these institutional arrangements place immigrant parents into a disadvantaged position which translates into unfavourable consequences for their children's educational success. These findings are important since they also contribute to the explanation of crossnational differences in educational outcomes for the children of immigrants. However, it also dependents of what kind of involvement the education system asks for. In Austria, as Schnell shows, the education system is characterized by its half-day training system which shifts the responsibility to learn into the family home since additional tutoring and preparatory classes at the school are largely non-existent. In other words, parents need to instrumentally support their children in school related activities. As mentioned before, this might set children of immigrants into an unfavourable position. This is less the case in the French education system, for example, which is comprehensive and provides full day teaching. Here, the pressure to provide e.g. instrumental support is much lower for immigrant families. However, as shown in Keskiner's paper, the French education system also asks for parental involvement - mostly evident in the orientation process before choices for certain tracks in upper secondary education are 
made by the school board. Indeed, immigrant parents that have greater knowledge about the French education system and greater abilities in the French language (cultural capital) are again in an advantaged position. However, as Keskiner argues through her comparison between France and the Netherlands, the chances for children of (Turkish) immigrants to enter more prestigious school tracks are greater if the education system asks for family involvement before school choices are made instead of basing the school decision solely on merit, as it is in the Dutch education system. Thus, the institutional arrangements of national education system determine the relevance and type of family involvement that immigrant parents have to provide in order to set their children on the successful educational paths.

\section{Suggestions for future research}

The five contributions in this issue highlight several new and important insights on the relationship between family involvement and educational success or upward mobility by children of immigrants in Europe. The studies presented in this special issue suggest that the focus on family involvement is of great relevance, especially if one aims to understand patterns of educational success by children of immigrants against the odds of family disadvantage. In our concluding remarks we briefly reflect on a number of topics that we think should deserve attention in future research on the interconnection between family involvement and educational success by children of immigrants.

To begin with, we believe it is imperative to collect more systematic data on family involvement and its link to educational success for children of immigrants in Europe. Such a data collection would allow for a standardised analysis across a number of countries and immigrant origin groups and help to bring out country differences. The papers by Schnell and Keskiner in this volume underline the advantage of using such comparable cross-national data showing that different institutional settings determine the relevance of family involvement for educational success by children of immigrants. We further believe that immigrant specific surveys should include questions around family involvement that are geared towards non-instrumental support. Recent surveys frequently conceptualise family involvement as instrumental support, such as the amount of help with homework. However, as many contributions in this special issue highlight, immigrant parents develop alternative strategies of involvement that should be subject to future survey research (e.g. mobilising non-familial resources or the significance of parental aspirations). Moreover, our collection of papers provides evidence for the advantage of studying the importance of other family agents that significantly influence the schooling processes by children of immigrants, beyond their parents. Amongst them, older siblings seem to be of particular importance. We therefore suggest that future (survey based) studies should include measures of siblings' involvement in school related issues for the second-generation (beyond just the number of siblings in families). At the same time, we also think it is useful to supplement quantitative findings with results from qualitative follow-up interviews. In other words, mixedmethods research designs seem to be of great advantage when investigating the correlation between types of family involvement and the educational success by children of immigrants. Alternative strategies of involvement, such as notional or emotional support by immigrant parents, are oftentimes hard to examine through standardised survey items. Instead, as convincingly shown in the contribution by Moguérou \& Santelli, 
Rezai et al. or Keskiner in this special issue, follow-up interviews with survey respondents might help to uncover specific mechanisms by those who have overcome barriers and achieved educational success.

Second, there is a great deal of research to be done in Europe to bring alternative strategies of involvement by immigrant families to the fore. As stressed above, one key finding of this volume is that almost all immigrant groups across all countries and cities developed some sort of compensation strategies to support their children against their drawbacks of barriers to involvement. These alternative means of involvement range from non-instrumental supportive behaviour by parents to the involvement of other significant family members, such as older siblings. We suggest further that the influence of (older) siblings as well as alternative activities of family involvement should also become a major aspect when theorising divergent educational pathways by children of immigrants. We feel that the role of siblings is a major omission in the current literature on social mobility by the second-generation and that forthcoming studies would greatly benefit from such an extension especially when discussing upward mobility. Future studies in Europe would also profit from investigating in how far ethnic communities and their members are a safety net for immigrant parents to gain resources that are not available in the family home, but might facilitate upward mobility and education success of their children. For example, as shown by Zhou and colleagues for the US (Zhou, 1997; Zhou \& Kim, 2006) or recently by Fleischmann et al. (2011) for Belgium, ethnic communities might strengthen parental involvement and support parental efforts to secure their children's educational success ${ }^{3}$.

Finally, cross-national comparisons raise questions about the significant relevance of different parental involvement policies by educational governments which have been a central concern for in the integration of minority youths. In many European countries and cities, the policy expectation is that parents can act as partners in reinforcing the learning of schools, or, what has been called the 'continuity between home and schools' (Lovelace \& Wheeler, 2006; Ogbu, 1992). We think that comparative work is essential to unpack the effect of different national or local parental involvement policies which might also contribute to cross-national differences in outcomes by children of immigrants. For instance, it seems likely that one way process policies, in which schools making demands on parents to get involved, will lead to disadvantages for children of immigrants because immigrant parents are more likely to experience barriers to involvement (e.g. problems with language) and thus to reactive behaviour by immigrant parents. By linking empirical findings on family involvement and educational success by children of immigrants with the respective policies in place, we believe that crossnational differences will become clearer.

\section{Endnotes}

${ }^{1}$ There has been a long standing trajectory of studies conducted in the U. S. on parental involvement and engagement since the relationship of parents particularly to schooling has been earmarked by federal policies in closing the achievement gap between minorities and mainstream students, and in particular the case of Latinos in the U.S.

${ }^{2}$ The notion of parental support is a much larger construct than parental involvement, as it is generally conceptualised as the level of acceptance or warmth that 
parents express toward their children (Bean, Barber, \& Crane, 2006) and the perception that parents are actively engaged in the parenting process. It includes therefore also parenting styles.

${ }^{3}$ However, whether the ethnic community serves as source or trap depends largely on its institutional structure and the level of socioeconomic resources available among community members.

\begin{abstract}
Acknowledgements
This special issue has its origin in the workshop 'Family strategies and educational success of children of immigrants' held at the $9^{\text {th }}$ Annual Conference of the 'International Migration, Integration and Social Cohesion' Network (IMISCOE) at the University of Amsterdam in 2012. The workshop was organized by Rosita Fibbi, Maurice Crul, and the IMISCOE working group 'Education and Social Mobility'. This special issue is based on the contributions of the before mentioned workshop and has been gratefully supported with a grant of the IMISCOE working group on Education and Social Mobility. We would like to thank our contributors for their tremendous work they have invested into their texts, Karin Milovanovic for her continuous support throughout the publication process and the editorial board of CMS for offering to publish this special issue.
\end{abstract}

\title{
Author details
}

${ }^{1}$ Swiss Forum for Migration and Population Studies, University of Neuchatel, Neuchatel, Switzerland. ${ }^{2}$ University of Rotterdam \& Free University of Amsterdam, Rotterdam, Netherlands. ${ }^{3}$ University of Amsterdam, Amsterdam, Netherlands.

Received: 29 April 2014 Accepted: 28 November 2014

Published online: 06 October 2015

\section{References}

Bean, RA, Barber, BK, \& Crane, DR. (2006). Parental Support, Behavioral Control, and Psychological Control Among African American Youth The Relationships to Academic Grades, Delinquency, and Depression. Journal of Family Issues, 27(10), 1335-1355.

Bourdieu, P. (1980). Le capital social. Actes de la recherche en sciences sociales, 31, 2-3.

Brinbaum, Y, \& Cebolla-Boado, H. (2007). The school careers of ethnic minority youth in France. Success or disillusion? Ethnicities, 7(3), 445-474.

Brinbaum, Y, \& Kieffer, A. (2009). Trajectories of immigrants' children in secondary education in France: Differentiation and polarization. Population-E, 64(3), 507-554.

Charles, CZ, Roscigno, VJ, \& Torres, KC. (2007). Racial inequality and college attendance: The mediating role of parental investments. Social Science Research, 36(1), 329-352.

Coleman, JS. (1988). Social capital in the creation of human capital. American Journal of Sociology, 94, 95-121.

Crul, M. (1999). Turkish and Moroccan sibling support and school achievement levels: an optimistic view. Netherlands Journal of Social Sciences, 3(2), 110-127.

Crul, M. (2000). Breaking the circle of disadvantage. Social mobility of second-generation Moroccans and Turks in the Netherlands. In H Vermeulen \& J Perlmann (Eds.), Immigrants, Schooling and Social Mobility. Does Culture Make a Difference? (pp. 225-244). London/New York: MacMillan/St.Martin's Press.

Crul, M. (2013). Snakes and Ladders in Educational Systems: Access to Higher Education for Second-Generation Turks in Europe. Journal of Ethnic and Migration Studies, 39(3), 1383-1401.

Crul, M, Schnell, P, Herzog-Punzenberger, B, Wilmes, M, Slootman, M, \& Aparicio-Gomez, R. (2012). School careers of second-generation youth in Europe. Which education systems provide the best chances for success? In $M$ Crul, J Schneider, \& F Lelie (Eds.), The European Second Generation compared: Does the integration context matter? (pp. 101-164). Amsterdam: Amsterdam University Press.

Crul, M, Zhou, M, Lee, J, Schnell, P, \& Keskiner, E. (2012). Success against the odds. In M Crul \& JH Mollenkopf (Eds.), The Changing Face of World Cities: Young Adult Children of Immigrants in Europe and the United States (pp. 25-45). New York: Russell Sage Foundation.

Darling, N, \& Steinberg, L. (1993). Parenting style as context: An integrative model. Psychological Bulletin, 113(3), 487-496. doi:10.1037/0033-2909.113.3.487.

Dornbusch, SM, Ritter, PL, Leiderman, PH, Roberts, DF, \& Fraleigh, MJ. (1987). The relation of parenting style to adolescent school performance. Child Development, 58, 1244-1257.

Downey, DB. (1995). When bigger is not better: Family size, parental resources, and children's educational performance. American Sociological Review, 60(5), 746-761.

Downey, DB. (2001). Number of siblings and intellectual development: The resource dilution explanation. American Psychologist, 56(6-7), 497.

Epstein, JL. (1987). Toward a Theory of Family-School Connections: Teacher Practices and Parent Involvement. In K Hurrelmann, F Kaufmann, \& F Losel (Eds.), Social Intervention: Potential and Constraints (pp. 121-136). New York: De Gruyter.

Fan, X, \& Chen, M. (2001). Parental Involvement and Students' Academic Achievement: A Meta-Analysis. Educational Psychology Review, 13(1), 1-22. doi:10.1023/a:1009048817385.

Fernández-Kelly, P. (2008). The back pocket map: Social class and cultural capital as transferable assets in the advancement of second-generation immigrants. The ANNALS of the American Academy of Political and Social Science, 620(1), 116-137. 
Fibbi, R, Topgül, C, Ugrina, D, \& Wanner, P (Eds.). (2015). The new second generation: Youth of Turkish and former Yugoslav descent in Zurich and Basel. Amsterdam: Amsterdam University Press.

Fleischmann, F, Phalet, K, Neels, K, \& Deboosere, P. (2011). Contextualizing Ethnic Educational Inequality: The Role of Stability and Quality of Neighborhoods and Ethnic Density in Second-Generation Attainment. International Migration Review, 45(2), 386-425.

Furstenberg, FF, \& Kaplan, S. (2003). Social Capital and the Family. In J Scott, J Treas, \& M Richards (Eds.), The Blackwell Companion to Sociology of Families (pp. 218-221). Malden, MA: Blackwell Publishing.

Gauthier, AH, Smeedeng, TM, \& Furstenberg, FF. (2004). Are parents investing less time in children? Trends in selected industrialized countries. Population and Development Review, 30(4), 647-671.

Glick, JE, \& White, MJ. (2003). Academic trajectories of immigrant youths: Analysis within and across cohorts. Demography, 40(4), 759-783.

Heath, AF, \& Brinbaum, Y. (2007). Explaining ethnic inequalities in educational attainment. Ethnicities, 7(3), 291-306.

Heath, AF, Rothon, C, \& Kilpi, E. (2008). The Second Generation in Western Europe: Education, Unemployment, and Occupational Attainment. Annual Review of Sociology, 34, 211-235.

House, JS. (1981). Work stress and social support. Reading, MA: Addison-Wesley.

Jeynes, WH. (2007). The Relationship Between Parental Involvement and Urban Secondary School Student Academic Achievement A Meta-Analysis. Urban education, 42(1), 82-110.

Kao, G. (2004). Social Capital and Its Relevance to Minority and Immigrant Populations. Sociology of Education, $77(4), 172-183$.

Kao, G, \& Joyner, K. (2004). Do Race and Ethnicity matter among friends? The Sociological Quarterly, 45(3), 557-573.

Kao, G, \& Thompson, JS. (2003). Racial and Ethnic Stratification in Educational Achievement and Attainment. Annual Review of Sociology, 29, 417-442.

Kao, G, \& Tienda, M. (1995). Optimism and Archievement: The Educational Performance of Immigrant Youth. Social Sience Quarterly, 76(1), 1-19.

Lareau, A. (2002). Invisible Inequality: Social Class and Childrearing in Black Families and White Families. American Sociological Review, 67(5), 747-776.

Lareau, A, \& Mc Namara Horvat, E. (1999). Moments of Social Inclusion and Exclusion. Race, Class, and Cultural Capital in Family-School Relationships. Sociology of Education, 72(1), 37-53.

Lee, J-S, \& Bowen, NK. (2006). Parent Involvement, Cultural Capital, and the Achievement Gap Among Elementary School Children. American Education Research Journal, 43(2), 193-218.

Lovelace, S, \& Wheeler, TR. (2006). Cultural discontinuity between home and school language socialization patterns: implications for teachers. Education, 127(2), 303-309.

Malecki, CK, \& Demaray, MK. (2003). What Type of Support Do They Need? Investigating Student Adjustment as Related to Emotional, Informational, Appraisal, and Instrumental Support. School Psychology Quarterly, 18(3), 231-252

McNeal, RB. (2012). Checking In or Checking Out? Investigating the Parent Involvement Reactive Hypothesis. The Journal of Educational Research, 105(2), 79-89. doi:10.1080/00220671.2010.519410.

McNeal, RN. (1999). Parental Involvement as Social Capital: Differential Effectiveness on Science Achievement, Truancy, and Dropping Out. Social Forces, 78(1), 117-144.

Ogbu, JU. (1992). Understanding cultural diversity and learning. Educational Res., 21(8), 5-14

Pong, S, Hao, L, \& Gardner, E. (2005). The Roles of Parenting Styles and Social Capital in the School Performance of Immigrant Asian and Hispanic Adolescents. Social Science Quarterly, 86(4), 928-950.

Portes, A, \& Fernandez-Kelly, P. (2008). No margin for error: Educational and occupational achievement among disadvantaged children of immigrants. The ANNALS of the American Academy of Political and Social Science, 620(1), 12-36.

Portes, A, \& Rivas, A. (2011). The adaptation of migrant children. The Future of Children, 21(1), 219-246.

Rosenbaum, E, \& Rochford, JA. (2008). Generational patterns in academic performance: The variable effects of attitudes and social capital. Social Science Research, 37(1), 350-372.

Ryan, CS, Casas, JF, Kelly-Vance, L, Ryalls, BO, \& Nero, C. (2010). Parent involvement and views of school success: the role of parents' Latino and White American cultural orientations. Psychology in the Schools, 47(4), 391-405.

Santelli, E. (2013). Upward social mobility among Franco-Algerians. The role of family transmission. Swiss Journal of Sociology, 39(3), 551-573.

Schnell, P. (2014). Educational mobility of second-generation Turks. Cross-national perspectives. Amsterdam: Amsterdam University Press (IMISCOE Research).

Schnell, P, Azzolini, D. (2015). The Academic Achievements of Immigrant Youths in New Destination Countries: Evidence from Southern Europe. Migration Studies, 3(2), 217-240.

Schnell, P, \& Crul, M. (2014). Inclusive education for children of immigrants: The Turkish second generation in Sweden, the Netherlands and Austria. In J Szalai \& C Schiff (Eds.), Being 'vissibly different': Post-colonial, migrant, and Roma youths in education across Europe (pp. 34-50). Houndmills/Basingstoke: Palgrave Macmillan.

Schnell, P, Keskiner, E, \& Crul, M. (2013). Success against the Odds: Educational pathways of disadvantaged second-generation Turks in France and the Netherlands. Education Inquiry, 4(1), 763-785.

Spera, C. (2005). A Review of the Relationship Among Parenting Practices, Parenting Styles, and Adolescent School Achievement. Educational Psychology Review, 17(2), 125-146. doi:10.1007/s10648-005-3950-1.

Steinberg, L, Lamborn, SD, \& Dornbusch, SM. (1992). Impact of Parenting Practices on Adolescent Achievement: Authoritative Parenting, School Involment, and Encouragement to Succeed. Child Development, 63(5), 1266-1281.

Tolsma, J, Coenders, M, \& Lubbers, M. (2007). Trends in Ethnic Educational Inequalities in the Netherlands: A Cohort Design. European Sociological Review, 23(3), 325-339.

Turney, K, \& Kao, G. (2009). Barriers to School Involvement: Are Immigrant Parents Disadvantaged? The Journal of Educational Research, 102(4), 257-271. 
Zhou, M. (1997). Segmented assimilation: Issues, controversies, and recent research on the new second generation. International Migration Review, 31(4), 975-1008.

Zhou, M, \& Bankston, CL. (1998). Growing up American : How Vietnamese children adapt to life in the United States. New York: Russell Sage Foundation.

Zhou, M, \& Kim, SS. (2006). Community Forces, Social Capital, and Educational Achievement: The Case of Supplementary Education in the Chinese and Korean Immigrant Communities. Harvard Educational Review, $76(1), 1-29$

Submit your manuscript to a SpringerOpen ${ }^{\circ}$ journal and benefit from:

- Convenient online submission

- Rigorous peer review

- Immediate publication on acceptance

- Open access: articles freely available online

- High visibility within the field

- Retaining the copyright to your article

Submit your next manuscript at $\boldsymbol{\nabla}$ springeropen.com 